\title{
Summary Judgment Under Federal Practice
}

\author{
Leon R. Yankwich*
}

\section{INTRODUCTION}

\section{The Search for Procedural Reform}

The American community, and especially the western community, is litigious. The heterogenous character of the people, the rapid developnient of the country, the quick passage from a rural to an urban civilization, the constant change in ownership of property which these changes entail, the nobility of our population - are all contributing factors. They all imply more constant resort to court action to resolve conflicts. An added factor is the increase in governmental control, state and federal, which flows from the conplexities of our industrial civilization.

So courts multiply in number and character. And those who are charged with the administration of justice are constantly seeking new and speedier methods of attaining results through the judicial process. Hence, many procedural tools have been wrought, aiming at the elimination of sham claims and defenses.

Among the most important ones is the provision for summary judgment embodied in Rule 56 of the Federal Rules of Civil Procedure. It is the aim of this study to examine the working of the rule and how it has fared before the federal courts of appeal. The effectiveness of this and of any other rule of procedure lies not so much in the manner in which trial judges envisage it, but in the manner in which the courts of appeals reviewing the work of the trial judges treat it. So the discussion to follow will be limited, in the main, to cases decided in the higher courts.

\section{Our Indebtedness to English Procedural Reformers}

The problem of our indebtedness to English procedural reformers is for the social scientist. English civil procedure for centuries was bound rigidly by the rigor of the common law rules. By contrast, few American States followed the strict common law pleading or procedure. Even before the rise of code pleading, which began with the adoption of the New York (Field) Code in 1848, there were practice acts in various states, which anticipated the innovations which the system of code pleading was later to establish permanently. In England, the reform of civil procedure began with what are known as the Hilary Rules of 1834. Nonetheless, and despite the traditional American reformist spirit, ${ }^{1}$ sone of the most fruitful recent innovations in the realn of civil procedure, such as the declaratory judg-

* Chief Judge of the United States District Court, Southern District of California.

1 Ciark, Code Pleading 21-31 (2d ed. 1947). 
ment ${ }^{2}$ and liberal rules of joinder, ${ }^{3}$ originated in the rule-making of English judges. To them, also, goes the credit for the summary judgment.

\section{THE ANTECEDENTS OF SUMMARY JUDGMENT}

The Advisory Committee on the Federal Rules has defined summary judgment in a single sentence: "Summary judgment procedure is a method for promptly disposing of actions in which there is no genuine issue as to any material fact." "4

Rudimentary provisions applicable to actions upon bills of exchange and promissory notes were enforced in England by rule as early as 1855 . The Judicature Act of 1875 broadened them. The English rule, as it exists today, began with the adoption in 1893 of Order 14 of the Supreme Court.5 In the United States, New Jersey was the first to adopt summary judgment in 1912. It was adopted in New York in $1926 .^{\circ}$ In California, it was first adopted in 1925, but limited to municipal courts. In 1933, it was extended to other trial courts. ${ }^{i}$ From the very beginning, the English courts conceived the object of the rule, which confined the motion to the claimant and applied to certain commercial transactions only, to be the exclusion of frivolous defenses. In an early case, which arose in 1878, under Order XIV of the Judicature Act of 1875 , Jessell, Master of the Rolls, stated in the Court of Appeal that the Order "is intended to prevent a man, clearly entitled to money, from bemg delayed where there is no fairly arguable defence to be brought forward." As to the duty of the court in giving effect to the Order, he said:

I agree entirely with the Vice-Chancellor, that when the judge is satisfied not only that there is no defense, but no fairly arguable point to be argued on behalf of the defendant, it is his duty to give effect to this section, and to give judgment for the plaintiff. ${ }^{9}$

This norm was followed in later cases arising under the broadened rule. Lord Esher, M.R., speaking for the Court of Appeal, stated the object of the Order in this manner:

The real meaning of Order XIV, rule 1 is, that where a plaintiff can shew to the satisfaction of a Judge that he has a cause of action which the defendant cannot possibly answer, then the Judge may direct final judgment to be entered at once for the plaintiff. Now, that is a stringent power to give and therefore this Court has said that the exercise of this power must be carefully watched, to see that the plaintiff has brought himself within

2 Yankwich, Declaratory Judgments, 1 F.R.D. 295 (1940).

3 Yankwich, Joinder of Parties in the Light of Recent Statutory Changes, 2 So. CarIr. L. REv. 315, 321 (1929).

4 Advisory Conatittee Notes, Fed. R. Civ. P. 56.

5 Buriand and Burnetr-HaIt, 1 The AnNuad Practice 169 (1951).

6 Shientag, Suntacary Judgaient 3 (1941); Clark, Code Pleading 556 et seq.

r Cad. Code Crv. Proc. $\$ 437$ (c), which superseded Cac. Code Crv. Proc. $\$ 831$ (d), which applied solely to municipal courts.

8 Anglo-Italian Bank v. Wells (and Davies), 38 L.T. 197 (C.A. 1878).

9 Anglo-Italian Bank v. Wells (and Davies), supra note 8 at 200-201. 
the order. But the Court did not mean by that to give effect to every trifing objection that might be taken. There must be a cause of action to which the defendant has no possible answer. ${ }^{10}$

In the particular case, the defendant had given a check upon his bank to the plaintiff. Later he dishonored it. In opposing the order, the defendant argued that there was no showing that notice of dishonor had been given to the defendant. But the court held that, as the defendant admitted owing - the money to the plaintiff for which the check was given, the absence of notice of dishonor was "a useless objection to put forward."

On the other hand, the same Lord Esher, in another case, insisted: "A defendant ought not to be shut out from defending unless it was very clear indeed that he had no case in the action under discussion." 12 In that case, although it appeared from the evidence that the defendant owed $£ 7500$ to the plaintiff, the defendant had a counterclaim for damages which might exceed that amount. The Court of Appeal, therefore, modified the order of the trial court by staying execution on the judgment in favor of the plaintiff until the trial of the counterclaim. In all these cases, the court, while giving full effect to the scope of the order, insisted that it be used with great care.

\section{SUMMARY JUDGMENT UNDER THE CONFORMITY STATUTE}

Summary judgment was brought into federal procedure by the new Federal Rules of Civil Procedure. ${ }^{13}$ However, under the rule-making power given to it, the old Supreme Court of the District of Columbia adopted a rule on October 21, 1870, which allowed summary judgment to be entered $\dot{m}$ an action ex contractu after the filing of a verified claim by the plaintiff unless the defendant filed along with any plea in bar

an affidavit of defense, denying the right of the plaintiff as to the whole or some specified part of his claim, and specifically stating also, in precise and distinct terms, the grounds of his defense, which must be such as would, if true, be sufficient to defeat the plaintiff's claim in whole or in part. ${ }^{14}$

If the defendant in his affidavit acknowledged his liability for a part of the plaintiff's claim, the plaintiff, if he so chose, could have judgment for the amount so confessed. The right of the Congress to delegate to courts the power to make rules and the validity of the particular rule were sustained by the Supreme Court. ${ }^{15}$ The basis for the decision which foreshadowed the later rulings upholding the constitutionality of summary judg-

10 Roberts v. Plant, 64 L.J.Q.B. 347, 350 (1895).

11 Roberts v. Plant, supra note 10 at 351 .

12 Sheppards and Co. v. Wilkinson and Jarvis, 6 T.L.R. (C.A. 1889). Later cases make the stay discretionary where the claim is based on a bill of exchange and a counterclaim is asserted. Lamont and Co., Ltd. v. Hyland Limited (No. 2), 66 T.L.R. 940 (C.A. 1950).

13 FED. R. Cw. P. 56.

14 Cropley v. Vogeler, 2 App. D.C. 28, 29 (1893).

15 Fidchty \& Deposit Co. v. United States, 187 U.S. 315 (1902). Previously, the Court of Appeals for the District of Columbia had also sustained the rule. Bank v. Hitz, MacArthur \& Mackey's 198 (1879); Cropley v. Vogeler, supra note 14. 
ments was that there was no constitutional right in a procedural form and that a rule which compels the sifting out of unmeritorious defenses does not violate due process. ${ }^{16}$

Federal courts, sitting in States which had summary judgments, adopted the procedure under the Conformity Act. ${ }^{17}$ Litigants in federal courts in those States were, therefore, beneficiaries of this method of disposing of frivolous claims or defenses. ${ }^{18}$ However, the Court of Appeals for the Ninth Circuit refused to sustain a summary judgment rendered in California in. a case brought under a war insurance policy against the Government under the World War Veterans' Act of $1924^{10}$ and the Tucker Act. ${ }^{20}$ While conceding that federal courts, under the Conformity Act, had recognized provisions for summary judgment as controlling in federal courts, the court, from the history of the two Acts under consideration, concluded that they both required that proof should precede the rendition of any judgment against the Government. The court was convinced that the history of the Acts manifested a clear intent that claims under the World War Veteran legislation should not be disposed of in a summary manner. ${ }^{21}$

SCOPE OF RULE 56, FEDERAL RULES OF CIVIL PROCEDURE

As it stands today, Rule 56 reads:

(a) FOR CLAIMANT. A party seeking to recover upon a claim, counterclaim, or cross-claim or to obtain a declaratory judgment may, at any time after the expiration of 20 days from the commencement of the action or after service of a motion for summary judgment by the adverse party, move with or without supporting affidavits for a summary judgment in his favor upon all or any part thereof. As amended Dec. 27, 1946, effective March $19,1948$.

(b) FOR DEFENDING PARTY. A party against whom a claim, counterclaim, or cross-claim is asserted or a declaratory judgment is sought, may, at any time, move with or without supporting affidavits for a summary judgment in his favor as to all or any part thereof.

(c) MOTION AND PROCEEDINGS THEREON. The motion shall be served at least 10 days before the time fixed for the hearing. The adverse

16 Chisholm v. Gilmer, 299 U.S. 99 (1936); Dewey v. Clark, 180 F.2d 766, 770-771

(D.C. Cir. 1950). And see Gen. Investment Co. v. Interborough R. T. Co., 235 N.Y. 133, 139

N.E. 216 (1923) ; Cowan Oil \& Refining Company v. Miley Petroleum Corporation, 112 Cal. App. Supp. 773, 295 Pac. 504 (1931) ; Bank of America v. Oil Well S. Co., 12 Cal. App. 2d 265, 55 P. 2 d 885 (1936).

1717 SrAr. 197 (1872), 28 U.S.C.A. $\$ 724$ (1927).

18 S. M. Hess \& Bro. v. Small, 288 Fed. 995 (E.D.N.Y. 1923) ; Massee \& Felton Lumber Co. v. Benenson, 23 F.2d 107 (S.D.N.Y. 1927) ; Maslin v. Columbian Nat. Life Ins. Co., 3 F. Supp. 368 (S.D.N.Y. 1932); United States v. Fiedler, 37 F. 2d 578 (E.D.N.Y. 1930); Hoff v. St. Paul-Mercury Indemnity Co. of St. Paul, 74 F.2d 689 (2d Cir. 1935), all arising under the New York statute, Rule 13, New York Rules of Civil Practice. Maryland Casualty Co. v. Sparks, 76 F.2d 929 (6th Cir. 1935), interpreting and applying the Michigan provision, Micr.

Court Rules ANn. (Searl, 1933) R.30.

1943 Stat. 612 (1924), 38 U.S.C.A. $\$ 445$ (1946).

2024 STAT. 506 (1887), 28 U.S.C.A. \$ 763 (1927).

21 United States v. Lindholm, 79 F.2d 784 (9th Cir. 1935). 
party prior to the day of hearing may serve opposing affidavits. The judgment sought shall be rendered forthwith if the pleadings, depositions, and admissions on file, together with the affidavits, if any, show that there is no genuine issue as to any material fact and that the moving party is entitled to a judgment as a matter of law. A summary judgment, interlocutory in character, may be rendered on the issue of liability alone although there is a genuine issue as to the amount of damages. As amended Dec. 27, 1946, effective March 19, 1948.

(d) CASE NOT FULLY ADJUDICATED ON MOTION. If on motion under this rule judgment is not rendered upon the whole case or for all the relief asked and a trial is necessary, the court at the hearing of the motion, by examining the pleadings and the evidence before it and by interrogating counsel, shall if practicable ascertain what material facts exist without substantial controversy and what material facts are actually and in good faith controverted. It shall thereupon make an order specifying the facts that appear without substantial controversy, including the extent to which the amount of damages or other relief is not in controversy, and directing such further proceedings in the action as are just. Upon the trial of the action the facts so specified shall be deemed established, and the trial shall be conducted accordingly.

(e) FORM OF AFFIDAVITS; FURTHER TESTIMONY. Supporting and opposing affidavits shall be made on personal knowledge, shall set forth such facts as would be admissible in evidence, and shall show affirmatively that the affiant is competent to testify to the matters stated therein. Sworn or certified copies of all papers or parts thereof referred to in an affidavit shall be attached thereto or served therewith. The court may permit affidavits to be supplemented or opposed by depositions or by further affidavits.

(f) WHEN AFFIDAVITS ARE UNAVAILABLE. Should it appear from the affidavits of a party opposing the motion that he cannot for reasons stated present by affidavit facts essential to justify his opposition, the court may refuse the application for judgment or may order a continuance to permit affidavits to be obtained or depositions to be taken or discovery to be had or may make such other order as is just.

(g) AFFIDAVITS MADE IN BAD FAITH. Should it appear to the satisfaction of the court at any time that any of the affidavits presented pursuant to this rule are presented in bad faith or solely for the purpose or delay, the court shall forthwith order the party employing them to pay to the other party the amount of the reasonable expenses which the filing of the affidavits caused him to incur, including reasonable attorney's fees, and any offending party or attorney may be adjudged guilty of contempt.

The amendments proposed by the Advisory Committee, submitted to the Congress by the Supreme Court on January 3, 1947, and which became effective on March 19, 1948 (to be referred to as "the 1947 amendments") made certain changes in the rule which should be adverted to before the rule is discussed in detail.

Prior to these amendments, the motion for summary judgment could be 
made "at any time after the pleading and answer thereto has been served."22 Thus, an answering defendant might be confronted with a motion for summary judgment before he has had an opportunity to employ counsel and is ready to file his answer. The amendment makes it impossible for the plaintiff to move for summary judgnient until after the expiration of 20 days from the commencement of the action. Before the amendment, a defendant could file a motion for summary judgment before the answer. ${ }^{23}$ But the plaintiff had to wait until the answer was filed before countering with his own motion.

The 1947 amendment to this rule permits the filing of a motion for summary judgment by the plaintiff immediately after his adversary has filed his. The amendment also introduced a change into Subdivision (c) of the rule, to make it certain that a summary judgment interlocutory in character could be entered on the question of liability leaving only the question of damages to be determined by trial. The amendment was made necessary by language used by some courts which could be interpreted as meaning that where the question of damages is open, the issue of liability could not be determined summarily. ${ }^{24}$

Certain general comments as to the scope of the rule are in order. By the use of the words "a party," the rule is intended to extend the right to "any" party to the action. And no distinction is made between the various types of action. Indeed, the Advisory Committee has stated emphatically: "This rule is applicable to all actions, including those against the United States or an officer or agency thereof." 25

Trial judges from the very beginning have taken the view that no differentiation should be made between the type of actions to which the procedure should or should not apply. In a matter which arose in the Southern District of New York involving the right to use "California" as a trademark, the judge, being convinced that there could be no appropriation of the geographical name of California or the descriptive word "sportswear," granted summary judgment, saying:

There appears no valid reason to differentiate between various types of action in testing the applicability of the Rule. Such a tendency is contrary to the purpose and spirit of the new federal procedural machinery .... The rule was intended to promptly dispose of actions in which there was no general issue of a material fact and to facilitate the operation of federal judicial machinery. The factors of each case decide the question of whether summary judgment should be granted, not the nature of the action. ${ }^{26}$

22 FED. R. CTV. P. 56(a) prior to amendment.

23 Lindsey v. Leavy, 149 F. 2d 899 (9th Cir. 1945) ; Gifford v. Travelers Protective Ass'n., 153 F.2d 209 (9th Cir. 1946). A motion by the plaintiff for summary judgment before the defendant's answer was filed was premature. Begnaud v. White, 170 F.2d 323 (6th Cir. 1948). 24 Sartor v. Arkansas Gas Corp., 321 U.S. 620 (1944). Madeirense Do Brasil S/A v. Stulman-Emrick Lumber Co., 147 F. 2d 399 (2d Cir. 1945).

25 Advisory Conamtrte Notes, Fed. R. CTv. P. 56.

20 California Apparel Creators v. Wieder of California, Inc., 68 F. Supp. 499, 507 (S.D. N.Y. 1946). 
Yet two months after this decision was made, Judge Learned Hand was warning the district judges against resorting to summary judgment in actions of a certain character. A summary judgment had been entered in an action for overtime under Section 16(b) of the Fair Labor Standards Act of $1938 .{ }^{27}$ The plaintiffs were maintenance and service employees. The affidavits showed that the building was owned by a bank which occupied 50 per cent of the rentable space. The remainder was occupied by tenants, of whom 16 per cent were firms doing a banking business, 6 per cent brokers and 20 per cent lawyers. In the circumstances, the trial court had found that no one in the building was engaged in "production of goods for commerce." 28 The court of appeals reversed, holding that the handling of bonds, bills of exchange, negotiable notes and commercial paper and other types of instrumentalities of investment might relate to commerce. It, therefore, decided that the district court was wrong in summarily dismissing the action, and uttered this warning:

In conclusion we cannot avoid observing that the case is another mistaken effort to save time by an attempt to dispose of a complicated state of facts on motion for summary judgment. This is especially true when the plaintiff must rely for his case on what he can draw out of the defendant .... It appears to be somewhat difficult to persuade the district courts of this; but we are satisfied that it is true. ${ }^{29}$

We shall have occasion to advert more fully in the discussion to follow to the limitations which appellate courts have placed upon the use of summary judgment. Some flow from the nature of the action, others from the hesitancy of courts to apply too freely this rigorous method of disposing of cases.

We continue with our analysis of the rule.

Statutes and rules in which this rule found its source, in many instances, such as in England ${ }^{30}$ and, in their original form, in New York ${ }^{31}$ and California, ${ }^{32}$ limit the remedy to the plaintiff. As already appears, the remedy under the federal rule is not so limited, and any party to an action may resort to it for the purpose of securing a summary disposition of the issues as to him. Whichever side resorts to the procedure, its object is not to determine an issue, but whether there is an issue to be tried.

2752 STAT. 1069 (1938), 29 U.S.C.A. \$ 216(b) (1946).

$2 \$ 52$ STAT. 1060 (1938), 29 U.S.C.A. \& 203(j) (1946).

29 Bozant v. Bank of New York, 156 F.2d 787, 790 (2d Cir. 1946). A similar warning was uttered in Doehler Metal Furniture Co. v. United States, 149 F.2d 130, 135-136 (2d Cir. 1945). See cases cited in note 77 infra. And see Colby v. Klune, 178 F. 2d 872 (2d Cir.1949).

30 Order 14 of the Supreme Court. And see cases cited in notes 8-12 supra.

31 N.Y. Rules Civ. Prac. 13 before its amendment in 1933. See Finch, Summary Judgment Procedure, 19 A.B.A.J. 504 (1933); Shrentag, Sungararx Judgment 11 et seq.

32 Car. Code CTv. Proc. $\$ 437$ (c), Cal. Stats. 1939, p. 1671. For a review of summary judgment in California prior to 1939, see McCabe, Summary Judgment, 11 So. CALr. L. REv. 436 (1938). Arizona (ARIz. Code ANn. c. 21, \$\$21.1210-1216 (1939), Colorado (Coto. Stat. ANr. c. 6, rule 56 (1935)), and New Mexico (N.M. Stat. ANN. c. 19, § 19-101(56) (1941)), also allow the motion to be made by either the plaintiff or the defendant in any civil action. In a few other States, summary judgment may be granted in a limited type of cases. See CrARK, Code Pleapivic 55\%-563. 
Agamst the summary disposition of an issue stands the fundamental right to trial in open court by adversary proceedings, and through testimony adduced therein of the issues tendered. The late Justice Cardozo has stated in simple, yet classic language, the condition which justified a departure, under summary judgment, from this principle:

To justify a departure from that course and the award of summary relief, the court must be convinced that the issue is not genuine, but feigned, and that there is in truth nothing to be tried..$^{33}$

And the Supreme Court of the Umited States, in interpreting this rule, has stated that it

authorizes summary judgment only where the moving party is entitled to judgment as a matter of law, where it is quite clear what the truth is, that no genuine issue remains for trial, and that the purpose of the rule is not to cut litigants off from their right of trial by jury if they really have issues to try..$^{34}$

In determining the matter, resort is had to extrinsic facts through affidavits, admissions and the like in order to find out if there is a real issue. This implies that such a finding will be made despite the fact that the pleadings as they stand present such issue. ${ }^{35}$

For this reason, the sufficiency of the complaint does not stand in the way of a motion on behalf of the defendant. ${ }^{36}$ The converse, of course, is also true. And the apparent adequacy of an answer does not prevent the granting of the plaintiff's motion, if the supporting documents show that no genuine defense exists. ${ }^{37}$

\section{GENUINE ISSUE UNDER STATE RULES}

We now consider the tests which have been evolved for determining whether there is or is not a "genuine issue as to any material fact." 38

The English rule, which was limited to the plaintiff, allowed judgment "if there is no defense to the action." 39 The New York rule ${ }^{40}$ uses the lan-

33 Curry v. MacKenzie, 239 N.Y. 267, 270, 146 N.E. 375, 376 (1925).

34 Sartor v. Arkansas Gas Corp., supra note 24.

अ Fletcher v. Krise, 120 F.2d 809, 812 (D.C. Cir. 1941); Miller v. Miller, 122 F. 2d 209, 212 (D.C. Cir. 1941) ; Koepke v. Fontecchio, 177 F.2d 125, 127 (9th Cir. 1949); Dewey v. Clark, supra note 16 at $770-772$.

36 Lindsey v. Leavy, supra note 23 ; William J. Kelly Co. v. Reconstruction Finance Corp., 172 F.2d 865, 866 (1st Cir. 1949); Wilkinson v. Powell, 149 F.2d 335 (5th Cir. 1945); Harris v. Railway Express Agency, 178 F.2d 8 (10th Cir. 1949); Hurd v. Sheffeld Steel Corp., 181 F.2d 269 (8th Cir. 1950) ; Compania De Remorque y Salvamento v. Esperance, 187 F.2d 114, 117 (2d Cir. 1951).

37 Battista v. Horton, Myers \& Raymond, 128 F.2d 29 (D.C. Cir. 1942) ; Gen. Investment Co. v. Interborough R.T. Co., supra note 16; Engl v. Aetna Life Ins. Co., 139 F.2d 469, 472473 (2d Cir. 1943); Albert Dickinson Co. v. Mellos Peanut Co., 179 F.2d 265, 267 (7th Cir. 1950). For a parallelism between these rulings and those of State courts, see United States Fidelity \& Guaranty Company v. Sullivan, 93 Cal. App. 2d 559, 561, 209 P.2d 429, 430 (1949). 38 FED. R. CIV. P. 56(c).

39 Order 14, R. 1, of the Supreme Court, 1893 ; BuRnand ANd Burnetr-HadL, THE ANNUAL PRACTICE 169.

40 N. Y. Rules Civ. Prac. 113. 
guage "that there is no defense to the action or that the action has no merit." The California rule, originally limited to the plaintiff, now allows summary judgment if it is claimed "that there is no defense to the action or that the action has no merit." 41

Making due allowance for the difference in approach between federal judges and state judges, inherent in the different materials with which they deal, and the litigation to which the summary judgment must apply, it is very significant that, in determining whether a genuine issue exists, the criteria evolved are so similar that the cases could readily be interchanged without changing the result arrived at in each particular case.

A few illustrations taken from the decided cases will illustrate the point. We have already adverted to some of the English cases. ${ }^{42}$ In a leading New York case, General Investment Co. v. Interborough Rapid Transit Co., in which the constitutionality of the New York rule was challenged, the action was upon a promissory note. ${ }^{43}$ The answer admitted execution and nonpayment. The defendant, however, denied, on information and belief, that the plaintiff was the owner of the note. Plaintiff moved for summary judgment, and at the hearing the notes were produced. The defendant having failed to submit positive proof, the court inferred ownership in the plaintiff from its possession of the notes, and production in court, and entered summary judgment. The New York Court of Appeals, affirming, said:

Under such circumstances the only reasonable conclusion the justice at Special Term could reach was that the denial in the answer was unfounded; that defendant had no defense to the action and the pleading was interposed solely for the purpose of delay in the administration of justice, a purpose designed to be obviated by the salutary provisions of the rule under which the application for summary judgment was made and granted. ${ }^{43 a}$

However, $m$ another case, for labor and material furnished in the construction of a yacht, where the affidavits raised the question whether payment had been made, the New York court held that a genuine issue of fact existed which could only be determined upon a trial.44

In a case before the Court of Appeals for the Second Circuit, decided under New York law, the same result was reached where the court, finding that the evidence was conflicting as to whether the insured's failure to attend trial was due to his refusal to cooperate with his insurer or the insurer's refusal to pay him expenses, ruled that the issue could not be disposed of summarily. ${ }^{45}$ The Court of Appeals for the Sixth Circuit, interpreting the Michigan summary judgment statute, ${ }^{46}$ reached the identical conclusion reached by the New York court in the General Investment

\footnotetext{
41 Cat. Code Crv. Proc. $\$ 437$ (c).

12 See cases cited notes $5,8,9,10,11$ and 12 supra.

43 Supra note 16.

$43 a$ Id, at 142,139 N.E. at 219.

44 Curry v. MacKenzie, supra note 33. See Croker v. Croker, 252 N.Y. 24, 168 N.E. 450

45 Hoff v. St. Paul-Mercury Indemnity Co. of St. Paul, supra note 18.

46 Mich. Court Rules ANw. 30 (Searl 1933).
} (1929). 
case. ${ }^{47}$ There, the action was on a county depositary's bonds. The execution of the bonds having been admitted, and the amount exceeding the security, the court held that summary judgment was properly granted. ${ }^{48}$

The California courts have been equally realistic in their approach. Where it was apparent that a check was given to secure noney to be used in gambling by the payor, the motion for summary judgment was sustained. ${ }^{49}$ Similarly, in an action on a deficiency judgment by a trustee under a deed of trust, where the defendant offered no evidence of fraud, unfairness or oppression committed by the trustee, but merely alleged that a bid offered by him was questioned, the motion for sunimary judgment was sustained. 50 And, in an action for breach of an alleged written contract to convey real estate where the affidavits showed that there was no written contract, as required by the state statute of frauds, summary judgment was held proper. ${ }^{51}$

By contrast, the following situations were held to present genuine issues which could not be disposed of summarily: in an action upon a judgment from a foreign state, whether partial payment had been received; ${ }^{52}$ in an action by a child under a property settlement agreement, whether the agreement, by its terms, provided for the plaintiff's maintenance, the contract not mentioning the child by name, but referring to "children." 53

Summary judgment is not proper where a contract is ambiguous and oral testimony nuay be necessary to determine whether it is sufficient under the statute of frauds. 54

A like ruling was made where an issue of accord and satisfaction by the acceptance of a promissory note was involved. ${ }^{55}$ The Supreme Court of California, in a leading case, has summed up its attitude in this manner:

The issue to be determined by the trial court in consideration of a motion thereunder is whether or not defendant has presented any facts which give rise to a triable issue or defense, and not to pass upon or determine the issue itself, that is, the true facts in the case .... If that were not true, controversial issues of fact would be tried upon affidavits by the court and not a jury. Because the procedure is summary and presented on affidavits without the benefit of cross-examination, a trial by jury and opportunity to observe the demeanor of witnesses in giving their testimony, the affidavits filed on behalf of the defendant should be liberally construed to the end that he will not be summarily deprived of the full hearing available at a trial of the action and the rights incident thereto. The procedure is drastic and

\footnotetext{
4i Gen. Investment Co. v. Interborough R. T. Co., supra note 16.

18 Maryland Casualty Co. v. Sparks, supra note 18.

49 Braverman v. Horn, 88 Cal. App. 2d 379, 198 P. 2d 948 (1948). See Williams Mfg. Co. 7. Prock, 184 F. 2d 307 (5th Cir. 1950); Silverman v. Osborne Register Co., 155 F. 2d 879 (D.C. Cir. 1946).

50 Security-First Nat. Bk. of L. A. v. Cryer, 39 Cal. App. 2d 757, 104 P.2d 66 (1940).

51 Ajax Holding Co. v. Heinsbergen, 64 Cal. App. 2d 665, 149 P. 2d 189 (1944).

50 United States Fidelity \& Guaranty Co. v. Sullivan, supra note 37.

53 Walsh v. Walsh, 42 Cal. App. 2d 282, 108 P.2d 760 (1940). See Walsh v. Walsh, 18 Cal. 2d 439, 116 P. 2d 62 (1941).

5s Gibson v. De La Salle Institute, 66 Cal. App. 2d 609, 152 P. 2d 774 (1944).

${ }^{55}$ Gardner v. Shreve, 89 Cal. App. 2d 804, 202 P.2d 322 (1949).
} 
should be used with caution in order that it may not become a substitute for existing methods in the determination of issues of fact. ${ }^{56}$

In the particular case, the fact which the supreme court held should have precluded granting a summary judgment was the allegation that a mortgage was accepted in payment for goods alleged to have been delivered, and that an agreement was entered into for discharge of the obligation on a monthly basis.

\section{GENUINE ISSUE UNDER THE FEDERAL RULE}

There is striking parallelism between the rulings just discussed and some of the rulings of the courts of appeal under Rule 56. Indeed, the Court of Appeals for the Third Circuit has used warning language almost identical with that just quoted from the Supreme Court of California. It said in a leading case:

In Merchants Indemnity Corporation of New York v. Peterson, 3 Cir., 1940,112 F. 2d 4, 6, we stated that "summary judgment may not be given under Rule 56 of the Rules of Civil Procedure if there be an issue presented as to the existence of any material fact." This principle was reiterated in Toebelman v. Missouri-Kansas Pipe Line Co., 3 Cir., 1942, 130 F. 2d 1016, in which we said, 130 F. 2d at page 1018: "Upon a motion for summary judgment it is no part of the court's function to decide issues of fact but solely to determine whether there is an issue of fact to be tried .... All doubts as to the existence of a genume issue as to a material fact must be resolved against the party moving for a summary judgment . . . ."57

The action sounded in fraud and plaintiffs alleged that they had been induced by the defendant to fraudulently cancel an order for certain machinery and to purchase similar machinery from another on the basis of various false representations as to the performance of the machinery originally ordered. Conflicting affidavits were filed. The trial court granted summary judgment because it accepted the version of the evidence narrated on behalf of defendants, as shown by affidavits "of people who are not parties to the action." The court of appeals held this to be error, using the language quoted.

Other courts of appeals have formulated the same criterion under similar circumstances. ${ }^{58}$

The pattern which emerges from the decided cases is not easy to delineate. Nevertheless, the cases present certain fundamental characteristics. The most important of these is that where the factual issue on the motion for summary judgment is simple and can be determined by the court without choosing between conflicting views, or relates to a question of law, such

56 Eagle Oil \& Refining Co. v. Prentice, 19 Cal. 2d 553, 555, 122 P.2d 264, 265 (1942).

57 Sarnoff v. Ciaglia, 165 F.2d 167, 168 (3d Cir. 1947). See Traylor v. Black, Sivalls \& Bryson, Inc., 189 F. 2d 213, 216 (8th Cir. 1951).

58 Doehler Metal Furniture Co. v. United States, supra note 29; Lindsey v. Leavy, supra note 23; Butcher v. United Electric Coal Co., 174 F.2d 1003, 1006 (7th Cir. 1949); Huntar v. Mitchell, 180 F. 2d 763, 764 (D.C. Cir. 1950). 
as jurisdiction, or the validity of a contract, or the application of a statute of limitations, judgment will be upheld.

Thus, shortly after Rule 56 was promulgated, summary judgment was properly upheld in an action for services by an attorney where it appeared that the attorney seeking compensation had been disbarred from practicing in the courts in which the services were alleged to have been rendered, the court saying that the purpose of Rule 56 "is to dispose of cases where there is no genuine issue of fact, even though an issue may be raised formally by the pleadings." "s9 And, in a border-line case, summary judgment was sustained in an action for breach of contract to sell lumber, where the breach was admitted and the damage flowing from non-performance could be determined without trial. ${ }^{60}$

In an action on a policy of life insurance, where it appeared that the deceased had not made full disclosure that she had consulted physicians, which failure would bar recovery, summary judgment was held justified. ${ }^{61}$ And where, in an action for personal injury by an employee of a railroad, it appeared that the injury was unconnected with employment and occurred on property not under the control of the railroad, summary judgment for the defendants was ruled proper. ${ }^{62}$

A similar conclusion was reached in the Court of Appeals for the Ninth Circuit, in an action by a seaman brought against the owners of a vessel, where it appeared that the defendant did not own the vessel and was not responsible for its unseaworthiness or for any negligent act committed on it to which the injury could be traced. ${ }^{63}$

Although courts are loathe to interfere with admimistrative bodies, where it appeared that certain claimed premises were decontrolled by the Housing and Rent Act of $1947,{ }^{64}$ and no administrative remedy existed for securimg an adjudication to that effect, the court entertained an action for declaratory relief, and, it appearing that the building was exempt, summary judgment against the Housing Expediter was sustained. ${ }^{65}$

59 Fletcher v. Krise, supra note 35. A similar ruling was made where it appeared that the debt sued on was given for an illegal consideration. Williams Mfg. Co. v. Prock, supra note 49; Silverman v. Osborne Register Co., supra note 49.

Go Madeirense Do Brazil S/A v. Stulman-Emrick Lumber Co., supra note 24.

01 Engl v. Aetna Life Ins. Co., supra note 37.

62 Wilkinson v. Powell, supra note 36 . Similarly, where undisputed facts showed adverse possession, Fife v. Barnard, 186 F. 2d 655 (10th Cir. 1951).

63 Thomas v. Furness (Pacific) Limited, 171 F. 2d 434 (9th Cir. 1948). See Harris v. Railway Express Agency, supra note 36, where non-liability appeared because the plaintiff was an emergency employee.

O4 61 STAT. 193 (1947), 50 U.S.C.A. App. § 1881 (1948).

as Koepke v. Fontecchio, supra note 35 . The opposite situation appeared in a case where war contractors asserted a right to additional compensation under the War Contracts Hardship Claims Act, 58 STAT. 652 (1944), 41 U.S.C.A. \$ 106 (1946). As the statute contemplates relief as a matter of grace, and not as of right, Fogarty v. United States, 340 U.S. 8, 12 1950), the court held that no recovery for a balance over and above the amount allowed by the agency (the Navy Department) could be had and sustained a summary judgment. Davidson v. Umited States, 185 F.2d 897 (D.C. Cir. 1950). But where the pleadings and affidavits presented an issue as to whether a civil service employe had been given a proper hearing before discharge, she was entitled to her day in court. Riley v. Titus, 190 F.2d 653 (D.C. Cir. 1951). A similar ruling was made where the question of the downgrading of a federal employee was imvolved. Hunter r. Mitchell, supra note 58 . 
It is evident from these illustrative cases that the remedy was effective where the affidavits showed clearly no issuable fact or the facts were undisputed and called merely for the application of the law to them. Where, however, the facts are complex and the court, in order to determine which way truth lies, would have to choose between conflicting versions of the same transaction, summary judgment does not lie.

Thus, in a copyright infringement case, where the defendants put in issue the assignment to the plaintiff of the copyright to Adolf Hitler's Mein Kampf, it was ruled that the issues should not be determined on the basis of the plaintiff's general affidavit, but on trial in which the plaintiff "should produce its evidence in the regular way and submit its witnesses to cross examination." "6s

And, in an action against the insurer of an automobile owner, where the right of the driver to use the automobile at the time of the accident was involved, a summary judgment of non-liability was improperly granted, the court saying:

The invoked procedure, valuable as it is for striking through sham claims and defenses which stand in the way of a direct approach to the truth of a a case, was not intended to, it cannot deprive a litigant of, or at all encroach upon, his right to a jury trial.

Judges in giving its flexible provisions effect must do so with this essential limitation constantly in mind. To proceed to summary judgment it is not sufficient then that the judge may not credit testimony proffered on a tendered issue. It must appear that there is no substantial evidence on it, that is, either that the tendered evidence is in its nature too incredible to be accepted by reasonable minds, or that conceding its truth, it is without legal probative force. Testing appellant's offer of proof by this rule, it plainly appears that an issue on which he is entitled to a jury trial has been summarily determined against him. ${ }^{67}$

On motions for summary judgment by both sides, in an action on a debt, the fact that the waiver of the statute of limitation would arise was held sufficient to prevent the summary judgment in favor of the defendants. ${ }^{68}$ To the contention that the existence of motions for summary judg-

66 Houghton, Miffin Co. v. Stackpole Sons, 113 F. 2d 627 (2d Cir. 1940). See cases cited note 76 infra.

67 Whitaker v. Coleman, 115 F.2d 305, 306 (5th Cir. 1940). However, where a recovery for personal injuries had been had in the State courts against the driver of an automobile, and, thereafter, an action on the judgment was begun in the United States district court against the insurer, sumniary judgment against the insurer was sustained where it appeared that the policy of insurance was written under a California city ordinance which required insurance coverage on rental cars and made liability dependent only on permissive use. The court held that, under the circumstances, a defense of failure to cooperate presented no issue as it was not available to the insured under the particular policy, or California Vehicle Code $\$ 402$. Royal Indemnity Co. v. Olmstead, 193 F.2d 451 (9th Cir. 1951). Where liability for personal injury depended on conflicting versions of the nature of the employment of the injured person, summary judgment for the defendant was held improper. Vale v. Bonnett, 191 F. 2d 334, 335-338 (D.C. Cir. 1951). A similar ruling was made by the same court in an action for possession of an apartnient where the tenant raised the question of the owner's good faith in seeking possession of the apartment for her own use. Dewey v. Clark, supra note 16.

68 Begnaud v. White, supra note 23 at 327. 
ment by both parties was an admission that no factual controversy exists, the court answered:

The fact that both parties make motions for summary judgment, and each contends in support of his respective motion that no genuine issue of fact exists, does not require the Court to rule that no fact issue exists. Each, in support of his own motion, may be willing to concede certain contentions of his opponent, which concession, bowever, is only for the purpose of the pending motion. If the motion is overruled, the concession is no longer effective. Appellants' concession that no genuine issue of fact existed was made in support of its own motion for summary judgment. We do not think that the concession continues over into the Court's separate consideration of appellee's motion for summary judgment in his behalf after appellants' motion was overruled. ${ }^{6}$

In a patent infringement case, where the issue of anticipation was tendered, it was ruled that the matter should not have been determined upon a motion for summary judgment. ${ }^{\text {TO }}$

An interesting situation arose in a recent case which went to the Supreme Court. Summary judgment for defendant had been granted in the lower court in an action in which the plaintiff had claimed a resulting trust to certaim realty. On appeal, the action of the court was sustained. But the Court of Appeals for the District of Columbia, in remanding the case, ordered a personal judgment against the defendant. The Supreme Court reversed, ruling that, as the summary judgment was limited only to the question of the resulting trust, the court of appeals could not order a personal judgment. The Court said:

Summary judgment may be given, under Rule 56, only if there is no dispute as to any material fact. There was no occasion in the trial court for Mrs. Fountain to dispute the facts material to a claim that a personal obligation existed, since the only claim considered by that court on her motion for summary judgment was the claim that there was a resulting trust. When the Court of Appeals concluded that the trial court should have considered a clain for personal judgment it was error to deprive Mrs. Fountain of an opportunity to dispute the facts material to that claim by ordering summary judgment against her. ${ }^{71}$

Notwithstanding the admomition of certain courts of appeals ${ }^{22}$ that certain cases should not be disposed of by summary judgment, the fact

69 Similar rulings were made in M. Snower \& Co. v. United States, 140 F. 2d 367, 369 (7th Cir. 1944); Walling v. Richnond Screw Anchor Co., 154 F.2d 780, 784 (2d Cir. 1946). However, in a more recent case, where the facts appeared fully from the affidavits, and the defendants stated that as to their special defenses they could offer no additional facts at the trial, sumniary judgment for the plaintiff was held proper. Tripp v. May, 189 F.2d 198 (7th Cir. 1951).

70 Bridgeport Brass Co. v. Boswick Laboratories, 181 F. 2d 315 (2d Cir. 1950). See Hazeltime Research, Inc. v. General Electric Co., 183 F. 2d 3 (7th Cir. 1950).

T1 Fountain v. Filson, 336 U.S. 681, 683 (1949).

72 See cases cited in note 29 supra. It should be noted that the question of defect in parties plaintiff cannot be raised on a motion for summary judgment. Cowling v. Deep Vein Coal Co, 183 F.2d 652, 656 (7th Cir. 1950). 
remains that the courts of appeals have not drawn any rigid lines which exclude resort to summary judgment in any type of case.

A search of the books discloses that the summary judgment has been used, often unsuccessfully, in cases arising under anti-trust laws; ${ }^{73}$ claims in bankruptcy; ${ }^{74}$ cases under a great variety of contracts and relating to their performance or breach $;{ }^{75}$ actions under copyright laws $;{ }^{76}$ claims under the Fair Labor Standards Act; ${ }^{77}$ fraud orders under the postal laws; ${ }^{78}$ cases arising under contracts of insurance; ${ }^{70}$ actions for libel where the privileged character of a publication appeared from the showing made on the motion for summary judgment; ${ }^{80}$ actions relating to patents and trade-

T3 International Salt Co. v. United States, 332 U.S. 392 (1947); Suckow Borax Mines, Consol. v. Borax Consolidated, 185 F. 2d 196 (9th Cir. 1950). But see American Fcderation of Tobacco Growers v. Neal, 183 F.2d 869 (4th Cir. 1950).

74 Beall v. Pinckney, 132 F.2d 924 (5th Cir. 1943), where, on summary judgment, the court found that a preferential and fraudulent conveyance had been made as to some of the parties. But where an issue of fact, such as receipt of a greater percentage of the creditor's debt under Section 60 of the Bankruptcy Act is tendered, no summary judgment may be rendered. Landy v. Silverman, 189 F.2d 80 (1st Cir. 1951); Spragute v. Vogt, 150 F.2d 795 (8th Cir. 1945). See Peckman v. Ronrico Corp., 171 F.2d 652, 658 (1st Cir. 1948), where, on the issuc of fraudulent conveyance, the court found that the pleadings presented "an irreconcilable conflict on material facts not susceptible of resolution by sumnary action."

is Silverman v. Osborne Register Co., supra note 49, where illegality of the contract appeared. See cases cited note 59 supra. But where, in answer to defendant's motion for sunimary judgment, plaintiff pleaded lack of consideration for a subsequent agreement to accept a smaller commission, summary judgment was held improper. Traylor v. Black, Sivalls \& Bryson, Inc., supra note 57. Sec Madeirense Do Brasil S/A v. Stulman-Emrick Lumber Co., supra note 24; Stevens v. Howard D. Johnson Co., 181 F.2d 390 (4th Cir. 1950); Brooks v. Pennsylvania R. Co., 187 F.2d 869 (2d Cir. 1951) ; Fairbanks, Morse \& Co. v. Consohidated Fisheries Co., 190 F.2d 817 (3d Cir. 1951).

76 Piantodosi v. Loew's Inc., 137 F.2d 534 (9th Cir. 1943); Christianson v. West Pub. Co., 149 F.2d 202 (9th Cir. 1945). But see MacDonald v. Du Maurier, 144 F. 2d 696 (2d Cir. 1944), where, because of similarity and possible access, judgment on the pleadings granted before the 1947 amendinents to the rules was reversed. And see cases cited note 66 silpra.

77 Generally, the issues presented in cases arising under this Act are too complicated to warrant disposition by summary judgment. See Walling v. Reid, 139 F. 2d 323 (8th Cir. 1943); Minor v. Washington Terminal Co., 180 F.2d 10 (D.C. Cir. 1950) ; Spencer v. Porter, 183 F. 2d 445 (8th Cir. 1950); Glenn v. Southern Cal. Edison Co., 187 F.2d 318 (9th Cir, 1951). But where the fact that no commerce is involved is undisputed, summary judgment will lic. Kam Koon Wan v. E. E. Black, 188 F.2d 558 (9th Cir. 1951).

i8 Fields v. Hannegan, 162 F.2d 17 (D.C. Cir. 1947); Pinkus v. Reilly, 170 F. $2 d 786$ (3d Cir. 1948).

T0 Fisher v. Underwriters at Lloyd's, London, 131 F.2d 1016 (7th Cir. 1942); Compania De Remorque y Salvamento, S. A. v. Esperance, Inc., stlpra note 36; Beidler \& Bookmyer, Inc. v. Universal Ins. Co., 134 F.2d 828 (2d Cir. 1943); Columbia Hospital v. United States Fidelity \& G. Co., 188 F.2d 654 (D.C. Cir. 1951). But sec Franklin Fire Ins. Co. of Philadelplia, Pa. v. Hanney, 149 F.2d 150 (9th Cir. 1945), where ambiguity of language required hearing as to circumstances; Kilbourn v. Western Surety Co., 187 F.2d 567 (10th Cir. 1951), where circumstances did not exclude inference of fraud.

80 Fletcher v. Evening Star Newspaper Co., 114 F.2d 582 (D.C. Cir. 1940). Sec also Fletcher v. Stephens, 133 F. 2d 394 (D.C. Cir. 1942). 
marks; ${ }^{81}$ actions for refunds under income tax laws; ${ }^{82}$ and matters relating to determination of status, such as marriage or remarriage. ${ }^{83}$ These are but a few of the types of cases in which the remedy has been sought. But they are indicative of the wide range.

Some writers have claimed that there is a hesitancy on the part of courts to decide some of the matters just enumerated, such as anti-trust, copyright and patents, by summary judgment. ${ }^{84}$ But an analysis of the cases shows clearly that the same pattern discernible in the rulings as to the application of the remedy to other cases runs through these cases. To refer to anti-trust cases, while the Court of Appeals for the Ninth Circuit hesitated to determine a suit for treble damages under the anti-trust laws on summary judgment, but sustained its dismissal on the ground of limitation, ${ }^{85}$ the Supreme Court found no difficulty in sustaining a summary judgment in favor of the Government in an equity anti-trust suit. ${ }^{86}$

In a preceding Note are found many cases in which summary judgment was rendered in patent and trademark cases. ${ }^{85}$ The patent cases in which

81 Stahley, Inc. v. M. H, Jacobs Co., 183 F.2d 914 (7th Cir. 1950) (trademark, where summary judgment was held proper when it appeared that the plaintiff had waived its trademark rights as to certain razors). But see, Avrick v. Rockmont Envelope Co., 155 F. 2d 568 (10th Cir. 1946) (trademark, where summary judgment was held improper because a visual comparison did not negative conclusively the possibility of confusion of source by the use of the two marks). For comment on this decision, see Mclville, Summary Judgment and Discovery, 34 A.B.A.J. 187 et seq. (1948). Compare the more liberal attitude of the same court as to summary judgment in an action arising under the Emergency Price Control Act of 1942, 56 STAT. 28 (1942), § 4(a), 50 U.S.C.A. App. \$ 904(a) (1944), Schreffler v. Bowles, 153 F. 2d 1 (10th $\mathrm{Cir}$. 1946). In the following patent cases, summary judgment was upheld upon the grounds set forth after each citation: Leishman v. Radio Condenser Co., 167 F.2d 890 (9th Cir. 1948) (showing that device did not infringe) ; Smith v. General Foundry Machine Co., 174 F.2d 147 (4th Cir. 1949) (non-infringement appearing from record on the motion) ; Steigleder v. Eberhard Faber Pencil Co., 176 F.2d 604 (Ist Cir. 1949) (comparison of devices showed non-infringement); Davison Chemical Corp. v. Johet Chemicals, Inc., 179 F. $2 \mathrm{~d} 793$ (7th Cir. 1950) (lack of invention appeared); Park-In-Theatres, Inc. v. Perkins, 190 F.2d 137 (9th Cir. 1951) (there was no invention) ; Hurd v. Sheffield Steel Corp., supra note 36 (coowner of patent was not joined as plaintiff). But see Frederick Hart \& Co., Inc. v. Recordgraph Corporation, 169 F.2d 580 (3d Cir. 1948), where summary judgment was held improper because a disputable question arose as to notice of infringement; Secretary Pen Co., Inc. v. Everlast Pen Corp., 186 F.2d 575 (2d Cir. 1951), where summary judgment was reversed because one of the claims seemed valid; Gray Tool Co. v. Humble Oil \& Refining Co., 186 F. $2 d 365$ (5th Cir. 1951), where the court held that monopolistic misuse of patent by the plaintiff could not be decided on summary judgment.

82 Noland v. Westover, 172 F.2d 614 (9th Cir. 1949), where, in a taxpayer's suit for refund, it appeared that the statute of limitations barred any claim for refund. But see, Kaspar v. Baron, 191 F.2d 737 (8th Cir. 1951), where claim of partnership by taxpayer was lield to prevent summary judgment for collector.

83 Matters of this character, whether they relate to marriage or other relationships, cannot usually he determined summarily. See Miller v. Miller, supra note 35, where, in an action for support under a foreign divorce decree, remarriage was held to present an issue requiring trial. See Hunter v. Mitchell, supra note 58, where the question of the downgrading of a federal employee was held to present a genuine issue.

84. Note, Summary Judgment in Federal Cases, 99 U. of PA. L. Rev. 212, 225-226 (1950). 85 Suckow Borax Mines Consol. v. Borax Consolidated, supra note 73. See American Federation of Tobacco Growers, Inc. v. Neal, supra note 73.

86 International Salt Co. v. United States, supra note 73. See Umited States v. Gypsum Co., 340 U.S. 76 (1950).

87 See cases cited note 81 supra; Dixon v. American Telephone \& Telegrapll Co., 159 F.2d 863 (2d Cir. 1947), where, in a patent case, laches appeared affirmatively. 
the remedy was refused were those in which issues, such as anticipation, were raised which could not be determined on affidavits. ${ }^{88}$ And the copyright cases in which the remedy was held inapplicable were those in which, because of access, it became important to determine whether the similarities were fortuitous or the result of copying. ${ }^{89}$

So the analysis leads to the conclusion that, where, from the nature of the action, the issues are few or simple and can be resolved by means of facts supplied by affidavits, or can be reduced to a legal problem showing the existence or non-existence of a valid claim or defense, the remedy is effective, and the action of the trial courts will be sustained.

But where the issues are complex, they do not lend themselves readily to disposition by this method.

\section{SOME GENERAL OBSERVATIONS}

As the object of this study is to deal with the status of Rule 56 before the courts of appeals, we need not concern ourselves with the mechanics of the motion for summary judgment. As already indicated, the motion may be asked either by the claimant ${ }^{00}$ or by the defending party. ${ }^{01}$ Reference has already been made to the changes as to time for bringing the motion, which the amendments of 1947 introduced. ${ }^{92}$

The motion must be based upon the pleadings, depositions and admissions on file, with the privilege of filing affidavits. The adverse party, prior to the hearing, may serve opposing affidavits. If the affidavits are unavailable, the court may, upon a showing, either refuse the application for judgment or order a continuance to permit affidavits to be obtained or depositions to be taken or provide for other methods of discovery. If the court is satisfied that the affidavits are presented in bad faith or for the purpose of delay, the party employing them may be penalized in costs incurred, including attorney's fees. The court may also punish the act as contempt.

Now for some comments on specific matters to which this schenie gives rise.

\section{(A) Contents of Affidavits}

A motion for summary judgment may be granted on the basis of pleadings, depositions, admission or of affidavits. ${ }^{93}$ When no affidavits are filed,

88Bowers v. E. J. Rose Mfg. Co., 149 F.2d 612, 615-616 (9th Cir. 1945); Bridgeport Brass Co. v. Bostwick Laboratories, Inc., supra note 70; Hazeltime Research, Inc. v. General Electric Co., supra note 70.

89 Arnstein v. Porter, 154 F. 2d 464 (2d Cir. 1946).

90 FED. R. CTV. P. 56(a).

01 FED. R. CIV. P. 56(b).

92 See text at notes 22-24 supra.

93 Gifford v. Travelers Protective Ass'n., 153 F.2d 209, 211 (9th Cir. 1946). Generally it is held that the filing of affidavits is not mandatory. See Fletcher v. Evening Star Newspaper Co., supra note 80 . Failure by the plaintiff to file counter affidavits does not, of itself, warrant the granting of summary judgment. Albert Dickinson Co. v. Mellos Peanut Co., supra note 37. But the plaintiff's silence may warrant giving full credit to the adversary's affidavits. See Foster v. General Motors Corp., 191 F.2d 907, 911-912 (7th Cir. 1951). 
the motion for summary judgment partakes more of the nature of a motion to dismiss for failure to state a claim or defense, ${ }^{9+}$ and the motion for judgment on the pleadings. ${ }^{95}$

If that were all that summary judgment could accomplish, it would be a cumulative remedy. For, in many instances, the pleadings show the existence of an apparent claim or defense. When this is the case, a motion without affidavits, or a motion to dismiss or for judgment on the pleadings, achieves nothing because the court is not in a position to go behind the pleadings. And it has been repeatedly stated that the chief object of the motion for summary judgment is to get behind the allegations of the complaint or answer and to show that, in reality, no claim or defense exists. ${ }^{96}$ This can be attained best by affidavits bringing into the record facts which do not appear on the face of the pleadings. This cannot, ordinarily, be done on a motion for dismissal or for judgment on the pleadings. For this reason, the rule, itself, has laid down the criteria to which the affidavits must conform.

(1) The courts frown on "unsupported suspicions." 97 For this reason, the primary requirement of the affidavits is that they shall state facts and be based on the personal knowledge of the moving party. ${ }^{98}$ This excludes expert testimony..$^{90}$ It also excludes allegations based on information and belief. ${ }^{100}$

(2) The facts must be admissible in evidence and the person making the affidavits must be competent to testify. ${ }^{101}$

\section{(B) Partial Adjudication}

Both before and after the 1947 amendments, it was contemplated that if judgment was not rendered upon the whole case, or for all the relief asked, and trial became necessary, the court on hearing of the motion should nevertheless ascertain the material facts which exist without controversy and make an order stating such facts, which may imclude the extent to which the amount of damages or other relief is not in controversy, and directing further proceedings. The facts so specified in the order are

94 FED. R. Crv. P. $12(\mathrm{~b})$.

95 Fed. R. CIV. P. 12 (c).

96 See cases cited under note 35 supra; Sabin v. Home Owners' Loan Corporation, 151 F.2d 541 (10th Cir. 1945); Rotberg v. Dodwell \& Co., 152 F. 2d 100 (2d Cir. 1945); Schreffer v. Bowles, supra note 81; Gifford v. Travelers Protective Ass'n., supra note 93; Barber v. Tadayasu Abo, 186 F.2d 775, 777 (9th Cir. 1951).

97 Griffin v. Griffin, 327 U.S. 220, 236 (1946).

${ }^{98}$ FED. R. CIv. P. 56 (e). See Hummel v. Wells Petroleum Co., 111 F. 2d 883 (7th Cir. 1940) ; Person v. United States, 112 F. 2d 1 (8th Cir. 1940); State of Washington v. Maricopa County, 143 F.2d 871 (9th Cir. 1944); Williams v. Kolb, 145 F.2d 344 (D.C. Cir. 1944). ${ }^{89}$ Sartor v. Arkansas Gas Corp., supra note 24.

${ }^{100}$ State of Washington v. Maricopa County, supra note 98 at 872; Jameson v. Jameson, 176 F. 2 d 58 (D.C. Cir. 1949).

101 FED. R. CIV. P. 56(e). If the witness is competent to testify, it matters not that he may, upon trial, claim immunity such as that of an ambassador. Banco De Espana v. Federal Reserve Bank, 114 F.2d 438, 444-445 (2d Cir. 1940). Or that he may not appear at the trial. Woods v. Turk, 171 F. 2d 244, 245 (5th Cir. 1948). 
deemed to be established for the purpose of the further proceedings. ${ }^{102}$ This is sometimes referred to as a "partial summary judgment." The phrase, however, involves a contradiction of terms. For a judgment is a final disposition of the controversy from which an appeal lies. ${ }^{103}$ And the courts have held definitely that an appeal from such partial order does not lie. ${ }^{104}$

The Advisory Committee has stated that the partial adjudication is "merely a pretrial adjudication that certain issues shall be deemed established for the trial of the case. This adjudication is more nearly akin to the preliminary order under Rule 16, and likewise serves the purpose of speeding up litigation by eliminating before trial matters wherein there is no genuine issue of fact." 105 The facts so found are binding upon the parties in all subsequent proceedings. ${ }^{108}$

It should be added that since the 1947 amendment to Subdivision (c) ${ }^{107}$ there is no question but that the court may determine liability by such order, leaving only the determination of the amount of damages for trial.

(C) Findings

The 1947 amendments to Federal Rule of Civil Procedure 52 specifically provide that no findings shall be necessary on a motion under Rule $56 .^{108}$ But they are still deemed necessary when only a partial determination is made. ${ }^{109}$

\section{(D) Motion to Dismiss as Motion for Summary Judgment}

Because the main object of such incidents of procedure as motions to dismiss or for judgment on the pleadings and summary judgment is to weed out unmeritorious claims and defenses, at times the choice of one rather the other inay have important results. So, in order to obviate the rule that, on a motion to dismiss, ${ }^{110}$ matters dehors the record cannot be considered, the rules were amended in 1947 to provide that if a motion to dismiss for failure to state a claim is made and matters outside the pleadings are presented and not excluded by the court, the motion is to be treated as one for summary judgment, and disposed of as provided in Rule 56. ${ }^{111}$ The same provision is made in case matters outside the pleadings are presented in a motion for judgment on the pleadings. ${ }^{112}$

102 FED. R. Crv. P. 56(d).

103 FED. R. CIV. P. 54(a).

104 Leonard v. Socony-Vacuum Oil Co., 130 F.2d 535 (7th Cir. 1942); Russell v. Barnes Foundation, 136 F.2d 654 (3d Cir. 1943); Biggens v. Oltmer Iron Works, 154 F. 2d 214 (7th Cir. 1946); Coffman v. Federal Laboratories, Inc., 171 F.2d 94 (3d Cir. 1948).

105 Advisory Comarties's Notes, Fed. R. CIV. P. 56.

${ }^{106}$ Houghton, Mifflin Co. v. Stackpole Sons, supra note 66 ; Parmelee v. Chicago Eye Shield

Co., 157 F.2d 582 (8th Cir. 1946).

107 FED. R. CIV. P. 56(c).

${ }_{108}$ FED. R. CIv. P. 52 (a). See Lindsey v. Leavy, sicpra note 23; Dulansky v. Iowa-Illinois Gas \& Electric Co., 191 F.2d 881, 883 (8th Cir. 1951). But see Bowers v. E. J. Rose Mfg. Co., supra note 88; Winter Park Tel. Co. v. Southern Bell Tel. \& Tel. Co., 181 F. 2d 341 (5th Cir. 1950). And see Simpson Bros. v. District of Columbia, 179 F.2d 430 (D.C. Cir. 1949).

109 Associates Discount Corporation v. Crow, 110 F. 2 d 126 (D.C. Cir. 1940); Russell v.

Barnes Foundation, supra note 104; Coffman v. Federal Laboratorics, Inc., supra note 104.

110 FED. R. CIV. P. 12 (c).

111 FED. R. CIV. P. 12(b).

112 FED. R. Civ. P. 12 (c). 
Since the adoption of these changes, the courts have treated all such motions as motions for summary judgment and determined them according to the rules relating to it. ${ }^{113}$

\section{(E) Fate of Counterclaim}

The existence of a counterclaim has given rise to a troublesome problem ever since the rule as to summary judgment was first promulgated in England. The English courts solved it by rendering a judgment on the plaintiff's 'claim and staying execution on it until the trial of the counterclaim. ${ }^{114}$

Under our procedure, the matter is complicated by the question whether the counterclaim is a compulsory counterclaim arising out of the same transaction, which must be asserted, ${ }^{115}$ or a permissive counterclaim. ${ }^{116}$ As the compulsory counterclaim must be asserted under penalty of losing the right to assert it, it would seem that when this is the case, the court cannot enter a summary judgment. At most, it can make a partial determination of issues to be followed by a full trial. There are cases supporting such action. $^{117}$

In case of a permissive counterclaim, it would seem that the court would have two alternatives. It could grant summary judgment to the plaintiff and order a separate trial of the counterclaim. Or it could, as do the English courts, grant judgment on the main claim, reserve trial on the counterclaim, and, in the meantime, stay execution on the main claim. ${ }^{118}$

\section{CONCLUSION}

Some years ago, a State trial judge of long experience said of summary judgment: "There is no more effective weapon in the arsenal of legal ad-

113 William J. Kelly Co. v. Reconstruction Finance Corporation, supra note 36; Lane Bryant, Inc. v. Maternity Lane, 173 F.2d 559 (9th Cir. 1949); Suckow Borax Mines Consol. v. Borax Consolidated, supra note 73; Chappell v. Goltsman, 186 F. 2d 215 (5th Cir. 1950); Compania De Remorque y Salvamento, v. Esperance, Inc., supra note 36 . But see Moffett v. Counmerce Trust Co., 187 F.2d 242 (5th Cir. 1951), where, notwithstanding the presence of affidavits, ruling of trial court dismissing complaint for failure to state a claim was sustained.

114 See cases cited in note 12 supra.

115 FED. R. CIV. P. 13(a).

116 Fen. R. Crv. P. 13(b).

117 Audi Vision, Inc. v. RCA Mfg. Co., 136 F. 2d 621 (2d Cir. 1943); Parmelee v. Chicago Eye Shield Co., supra note 106; Garrett Biblical Institute v. American University, 163 F.2d 265 (D.C. Cir. 1947).

118 See cases cited note 12 supra. For additional English cases dealing with the effect of counterclaims and set-offs on summary judgment, see BURNAND AND BURNETr-HAII, 1 THE Amnual Practice 194-195. There is a precedent in the New York state courts for summary judgment in favor of a planitiff for the excess of his claim over the counterclain, while reserving the counterclaim for trial. Irving Trust Co. v. Leff, 253 N.Y. 359, 171 N.E. 569 (1930). Where counterclaims are asserted, the rules authorize separate trials. FED. R. Crv. P. 13(i). When a trial is had on multiple claims, FED. R. CTv. P. 13(b), judgment may be rendered as to some claims less than all. FED. R. Crv. P. 54(b). Where the claims do not arise from the sane transaction, a separate final judginent as to one of the claims may be made. Reeves v. Beardall, 316 U.S. 283 (1942). It would seem, therefore, that by analogy the procedure sanctioned in Irving Trust Co. v. Leff, supra, could be followed in the case of a permissive counterclaim. See Irsen, Recent Developarents in Federal Practices and Procedore 271, 354-356 (unonograph published at the end of FederaI Ruzes of CivIL Procedure (West Pub. Co., 1947 rev. ed.)). 
ministration." 119 There are no means of showing the extent of its use in the district courts. In our own district, it is used very little and not often granted. But it is quite apparent, from a study of the decided cases, that the courts of appeals have dulled the weapon by the limitations which they have placed upon the rule. This was accomplished, first, by declining to allow district judges to weigh conflicting evidence. The fear in AngloAmerican jurisprudence of "trial by affidavits" may be the motivation behind this, and the feeling that such trial contravenes the right to have matters of fact decided by a jury under the constitutional guaranty. ${ }^{120}$

In addition, federal courts have circumscribed the use of the motion for summary judgment in certain types of controversy. This, as already appears, is due to the fact that, in the particular fields, facts are of such complexity that the truncated proceeding of summary judgment cannot defimitely determine the issues involved. Trial judges, especially those in metropolitan areas, confronted with ever increasing litigation, have shown eagerness to use this method of weeding out unmeritorious claims and defenses. At times, they have been restrained by warnings of the courts of appeal. ${ }^{121}$ Which brings us back to the fact that absolute simplicity is as illusory and difficult of attainment in procedure as it is in life. In a complex world, litigation will reflect complexity. Procedural reform may help achieve quick disposition of litigation at times. But the complexity inherent in the material out of which certain litigation arises, the litigious character of the American people, especially of the people of the West, the scrupulous determination of higher courts to have facts determined upon full trial, stand in the way of substituting even so desirable a reform as summary judgment for the average trial. Slow as the judicial process may be at times, I am convinced that peace under law, which is the real object of a lawsuit, can best be achieved by a full-scaled airing of complicated controveries. Summary judgment may achieve limited ends. But if, through a more universal use, it achieved greater immediate objectives, the result might, in the long run, be harmful to the democratic process. ${ }^{122}$

119 ShIEntag, Sumarary JudgMent 1.

120 U.S. CONST. AMTEND. VII.

121 See cases cited note 29 supra. As said by Mr. Justice Jackson in Kennedy v. Silas Mason Co., 334 U.S. 249, 256-257 (1948): "But summary procedures, however salutary where issues are clear-cut and simple, present a treacherous record for deciding issues of far-flung import." See Elgin, J. \& E. R. Co. v. Burley, 325 U.S. 711 (1945) ; Pacific American Fisheries v. Mullaney, 191 F.2d 137 (9th Cir. 1951). Yet the Supreme Court has not hesitated to approve summary disposition when a legal principle, such as public pohicy, stood in the way of maintenance of an action. Morton Salt Co. v. Suppiger Co., 314 U.S. 488 (1942). See Palmer v. Chamberlin, 191 F.2d 532 (5th Cir. 1951).

${ }^{122}$ See Yankwich, The Limitations of Law and Judicature, 99 U. OF PA. I. REv. 171 (1950). And see the warning of Judge Jerome Frank of the Court of Appeals for the Second Circuit, on "trial by affidavit," in Colby v. Klune, supra note 29. For similar warnings by Judge Joseph C. Hutcheson, Jr. of the Court of Appeals for the Fifth Circuit, see Paul E. Hawkinson Co. v. Dennis, 166 F. 2d 61 (5th Cir. 1948); Gray Tool Co. v. Humble Oil \& Refining Co., supra note 81. See also Reynolds Metals Co. v. Metals Dismtegrating Co., 176 F.2d 90 (3d Cir. 1949). As to the importance of the inferences of trial judges from oral testimony and the right to reject even uncontradicted testimony, see Broadcast Music v. Havana Madrid Restaurant Corp., 175 F.2d 77, 80 (2d Cir. 1949). This opportunity is absent in proceedings "by affidavits." 